\title{
My view
}

Randy G. Westbrooks

U.S. Geological Survey

Whiteville, NC

rwestbrooks@weblnk.net
William P. Gregg

U.S. Geological Survey

Reston, VA
Robert E. Eplee

U.S. Department of Agriculture,

Retired

Whiteville, NC
Over the years, humans have become adept at manipulating the environment to suit their needs. One of the most far-reaching land use changes that has transformed vast areas of the Earth's surface is agriculture. As agriculture developed, weed control was born out of the need to protect crops from early successional invaders. Today, the ability of agriculture to produce enough food and fiber for the world's people is dependent on modern weed science. While the discipline of weed science has admirably risen to the challenge of crop protection over the past several decades, it has been less responsive to the problems of new agricultural weeds, as well as environmental weeds or invasive plants that threaten natural areas. A major new challenge for plant scientists is to develop systems for early detection and rapid response to new weeds, as well as technology for management of environmental weeds in ecosystems that are not being managed for agricultural production.

According to ecologists, the number two threat to biodiversity, right behind habitat destruction and loss, is introduced invasive species. This is occurring because the biogeographical barriers that permitted the evolution of the world's current biodiversity and also restricted the range of species since the break up of the supercontinent Pangea about 180 million yr ago are being breached through global travel and trade. While free trade without tariffs and quotas promises to improve the world economy, it also will create more and more pathways for movement of invasive species into new environments in different parts of the world. The homogenization of the world's flora and fauna and the lingering effects of introduced invasive species are unintended side effects of accelerating globalization. Both pose a serious threat to agricultural sustainability and to ecosystem biodiversity. Both deserve the full attention of weed scientists. With literally thousands of potential weeds around the world, and new pathways for them to spread, it is imperative that prevention become a higher priority in weed science.

Currently, biological wildfires are raging around the world, and more fuel is being added as global trade increases through marketing decisions made by people with little or no connection to agriculture or land management. Some of the introduced species that are beginning to appear each year will become the major invaders of the 21 st century. Wetland nightshade (Solanum tampicense Dunal) in southwest Florida and the floating fern giant salvinia (Salvinia molesta Mitch.), which is spreading across the southern tier of states, are good examples. In addition, without their coevolved predators and parasites, well-established invaders, such as melaleuca [Melaleuca quinquenervia (Cav.) Blake] in the Florida Everglades and yellow starthistle (Centaurea solstitialis L.) in the West, that smoldered in their initial lag phase for decades are now spreading rapidly. Wetland night- shade, giant salvinia, and scores of other new and invasive species will follow the same path if they are not eradicated soon. While invasive species represent a very small percentage of introduced species, they have set the stage for an ecological catastrophe with no modern corollary since the extinction of the dinosaurs. Weed scientists should play a prominent role in efforts to address such new invaders.

In the 1960s, the Weed Science Society of America was instrumental in the development and passage of the Federal Noxious Weed Act (FNWA) of 1974. The intent of the FNWA was to provide federal authority to prevent the introduction and spread of serious foreign weeds.

Currently, 95 taxa have been listed as Federal Noxious Weeds (see http://www.aphis.usda.gov/ppq/bats/fnwsbycate. html). However, since the passage of this law, very limited progress has been made in establishing a nationally coordinated program to detect and respond to new weeds. Unlike federal pest control programs, such as Mediterranean fruit fly (Ceratitis capitatis) and foot-and-mouth disease, which are fully supported by major commodity groups, the Federal Noxious Weed program has received minimal outside support; therefore, it may be largely considered an unfunded, unaddressed need. To help energize this program, weed scientists need to become more active in providing the knowledge and tools we need to prevent new weed invasions. Until prevention becomes an obvious priority in weed science, it will continue to be a challenge to persuade other people that prevention is important.

Because most invasive plants were intentionally introduced for some utilitarian purpose, another major challenge is to develop a system for screening all new imported plants for invasiveness. Under the current U.S. system, new fruits and vegetables proposed for importation are assessed for invasiveness and their potential to harbor prohibited insects and diseases. However, new species of nursery stock proposed for importation are assessed only for their potential to harbor insects and diseases. This means that most foreign plants can be legally introduced into the United States without any consideration of their potential invasiveness. To improve the U.S. plant introduction process, all proposed taxa should be assessed for invasiveness and should be classified under a standardized system for degrees of invasiveness and for appropriate regulatory action. The permitted list system, which has worked very well in Australia and New Zealand, could serve as a model for developing a permitted/prohibited list system in the United States. Under the Australian Weed Risk Assessment (WRA) system, all new plant imports are assessed by the Australian Quarantine and Inspection Service (AQIS) for invasiveness to determine if they will be permitted entry or placed on the federal prohibited plant list. This system is used on all new plant imports, whether 
they enter Australia as seeds, nursery stock, or tissue culture and regardless of their intended use in Australia. The WRA, which has been endorsed by Environment Australia as well as a wide range of client groups, has a permitted/rejection ratio of about $75 / 25 \%$, which although conservative, reflects Australia's concerns over imported plants becoming pests. (See http://www.aqis.gov.au/docs/plpolicy/weeds1.htm to find out more about the system.) Because the Australian system was developed by weed scientists, it seems logical that weed scientists should take a leading role in developing a permitted/prohibited list system in the United States. To have more influence in the debate over such issues, weed scientists must take a leading role in all aspects of weed management, from prevention through restoration, not just economic control in agricultural production systems.

Because many invasive species threaten both agricultural and natural ecosystems, we should not wait until they become a certified economic threat before we address them. Introduced species with a history of invasiveness abroad or with characteristics of invaders must be detected, reported, assessed, and if appropriate, eliminated as soon as possible. The development of a National Early Warning and Rapid Response System for Invasive Plants, which is now being developed under the auspices of the Federal Interagency Committee for the Management of Noxious and Exotic Weeds (FICMNEW) and in response to Presidential Executive Order \#13112 on Invasive Species, is critical. With increasing interest and a high level of concern about all types of invasive species, creation of the Early Warning System, as well as local weed management areas and state invasive species councils, provides a real opportunity for weed scientists to partner with ecologists, conservation biologists, and other specialists in new and effective ways.

The homogenization of the world's flora and fauna poses a clear and present danger to agricultural and managed production systems and to the biodiversity of natural areas. The challenge is real, and weed scientists, as well as our nation, can only benefit by focusing more attention on weed prevention and by addressing invasive plants of natural areas. 